\title{
Use of peroxidase-conjugated antiglobulin as an alternative to immunofluorescence for the detection of antinuclear factor in serum
}

\author{
J. DORLING, G. D. JOHNSON, JANET A. WEBB, AND MAVIS E. SMITH
}

\author{
From the Medical Research Council Rheumatism Unit, Canadian Red Cross Memorial Hospital, \\ Taplow, Maidenhead, Berkshire
}

SYNOPSIS A method of detecting serum antinuclear factor by the use of antiglobulin conjugated with horseradish peroxidase has been compared with a standard procedure using a fluorescent label. The horseradish peroxidase conjugate was evaluated by block titration against positive serum and by its performance as a test reagent for screening and titrating sera. It is concluded that the horseradish peroxidase method, in which an ordinary light microsc ope is employed, provides a satisfactory alternative to immunofluorescence for routine tests for antinuclear factor.

It has been shown (Nakane and Pierce, 1966) that horseradish peroxidase can be coupled to antibody by a simple procedure to give stable conjugates which retain immunological reactivity and can be used for immunotracing in a similar manner to fluorescein-labelled antibody. In tissues treated with peroxidase conjugate the sites of uptake are made visible by a simple histochemical procedure. Peroxidase catalyses the oxidation by hydrogen peroxide of a number of substrates, in some cases producing a highly coloured insoluble reaction product.

The work of Nakane and Pierce (1966) and others (eg, Davey and Busch, 1970) suggests that the horseradish peroxidase method is at least as sensitive as the immunofluorescence technique. Nakane and Pierce (1966) state that 'this might be expected because enzyme is not consumed in the reaction with substrate, and each molecule of enzyme-labelled antibody bound to the antigenic site deposits many molecules of reaction product'.

Antibodies combining specifically with components of cell nuclei are characteristically found in the serum of patients with certain 'autoimmune' conditions, notably systemic lupus erythematosus, and are usually detected by the indirect fluorescent antibody method (Coons and Kaplan, 1950). This involves treating preparations containing nuclei, eg, tissue sections, with the patient's serum followed by staining with antiserum to human $\gamma$-globulin conjugated with a fluorescent dye. Nuclear fluorescence indicates a positive reaction. Since immunoReceived for publication 29 October 1970. fluorescence was first used for detecting antinuclear factor (Holborow, Weir, and Johnson, 1957) the method has undergone considerable development (Johnson, Beutner, and Holborow, 1967; Holborow and Johnson, 1969) to improve its usefulness in diagnosis and is increasingly used in clinical laboratories. Difficulties, however, are still encountered, especially those associated with the special requirements of fluorescence microscopy. These would be avoided by the use of a label such as horseradish peroxidase which could be rendered visible by conventional microscopy. In this paper we compare the sensitivity of the two procedures.

\section{Materials and Methods}

PATIENTS' SERA

These were drawn from the serum bank of this Unit, and were maintained at $-20^{\circ} \mathrm{C}$.

\section{FLUORESCENT CONJUGATE}

The globulin fraction obtained by precipitation of monospecific rabbit antiserum to human IgG with $50 \%$ saturated ammonium sulphate was conjugated with fluorescein isothiocyanate isomer $1(\mathrm{BDH})$ by a modification of the method described by Marshall, Eveland, and Smith (1958). After conjugation unreacted dye was removed by passing the solution through Sephadex G25. Analysis of the conjugate indicated a protein concentration of $8 \mathrm{mg} / \mathrm{ml}$ and a labelling ratio of $1 \cdot 1: 1\left(O_{495} \mathrm{~nm}: \mathrm{OD}_{280 \mathrm{~nm}}\right)$. It contained 4 units of precipitating activity (Beutner, 
Holborow, and Johnson, 1967) and was evaluated by block titration as previously described (Beutner et al, 1967) using the antinuclear factor system. A satisfactory working dilution was 1:40.

\section{FLUORESCENCE MICROSCOPY}

A Zetopan microscope (Reichert) fitted with HBO 200 high-pressure mercury vapour burner and cardioid condenser was used. The exciting filter was BG 12/3 mm (Schott and Genossen) and the barrier filter GG9 (Schott and Genossen).

HORSERADISH PEROXIDASE CONJUGATE (NAKANE AND PIERCE, 1966)

$0.25 \mathrm{ml}$ of $0.5 \% 4 \cdot 4^{\prime}$ difluoro $3 \cdot 3^{\prime}$ dinitro diphenyl sulfone $^{1}$ in acetone was added to $2 \mathrm{ml}$ of $0.5 \mathrm{M}$ carbonate buffer $p \mathrm{H} \quad 10.0$ containing $50 \mathrm{mg}$ of horseradish peroxidase ${ }^{2}$ and $50 \mathrm{mg}$ of a globulin fraction prepared from the same rabbit antiserum used for the fluorescein isothyocyanate conjugate. The mixture was gently agitated at $4^{\circ} \mathrm{C}$ for six hours, dialysed against $0.15 \mathrm{M} \mathrm{NaCl}$ containing $0.01 \mathrm{M}$ $\mathrm{PO}_{4}$ pH 7.2 ('PBS') overnight and the small amount of precipitate removed by centrifugation. An equal amount of saturated ammonium sulphate in distilled water was added and mixed gently by inversion. After standing for 30 minutes at $4^{\circ} \mathrm{C}$ the mixture was centrifuged for 15 minutes at $3,500 \mathrm{rpm}$ at $4^{\circ} \mathrm{C}$ and the supernatant containing free horseradish peroxidase was discarded. The precipitate was washed twice with $50 \%$ saturated ammonium sulphate in phosphate-buffered saline, resuspended in $0.5 \mathrm{ml}$ of phosphate-buffered saline, and dialysed against phosphate-buffered saline to remove ammonium sulphate.

\section{IMMUNOLOGICAL STAINING PROCEDURE}

The method previously described (Holborow and Johnson, 1969) was followed. Cryostat sections, $6 \mu$, were cut from snap-frozen blocks of fresh liver from Black Hood rats. Multispot slides (O'Neill and Johnson, 1970) were used to facilitate handling. All dilutions were made in phosphate-buffered saline. Staining was carried out in a damp chamber at room temperature, and the slides were washed after treatment with serum and conjugate, with the aid of a magnetic stirrer. Duplicate sections treated in parallel were stained either with fluorescein isothyocyanate or horseradish peroxidase conjugate. After washing, sections treated with the fluorescein conjugate were mounted in glycerol and examined under the fluorescent microscope. Sections tested with the horseradish

1Obtained from K \& K Laboratories Inc., U.K. Distributors Kodak Limited, Kirkby, Liverpool, England.

${ }^{2}$ Peroxidase (Horseradish) Grade II RZ Value 2-24. Seravac Ltd, Maidenhead, Berks. peroxidase conjugate were washed, stained for horse- 음 radish peroxidase by the method described below, and examined under a light microscope.

In each system tests were randomized and read independently without knowledge of their identity.

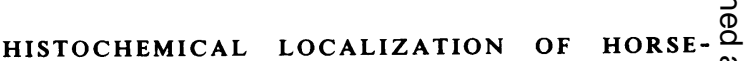
RADISH PEROXIDASE (GRAHAM AND KARNOV- ఝ SKY, 1966)

Preparation of substrate solution

3.3' diaminobenzidine tetrahydrochloride (Sigma $\bar{\omega}$ $-97.99 \%$ ) $-25 \mathrm{mg}$

$0.05 \mathrm{M}$ Tris/ $\mathrm{HCl}$ buffer $p \mathrm{H} 7.6-50 \mathrm{ml}$

$3 \%$ hydrogen peroxide $-0.15 \mathrm{ml}$

Substrate was freshly prepared for each batch of $\%$ sections and the hydrogen peroxide was added ${ }^{\circ}$ immediately before use.

\section{STAINING METHOD}

Sections were stained for 10 minutes at room tem- $\mathscr{\infty}$ perature in the substrate solution, washed briefly in $\frac{\vec{D}}{D}$ $0.05 \mathrm{M}$ Tris $/ \mathrm{HCl} p \mathrm{H} 7.6$ buffer followed by distilled $\bar{F}$ water, dehydrated in absolute alcohol, cleared in $\underset{-}{\mathbb{1}}$ xylene, and mounted in DPX (BDH).

\section{Results}

APPEARANCE OF SECTIONS STAINED WITH HORSERADISH PEROXIDASE CONJUGATE Sections that had been treated with antinuclear $\stackrel{\circ}{2}$ factor-positive sera showed deeply staining brown $\stackrel{1}{\varrho}$ nuclei, the rest of the tissue being only very faintly $\overrightarrow{\overline{0}}$ stained (Fig. 1a). Nuclei in sections treated with $\frac{3}{3}$ antinuclear factor-negative sera on the other hand were indistinguishable from the background (Fig. 1b). Leucocytes present in some sections invariably showed strong cytoplasmic staining due to the presence of endogenous peroxidase.

EVALUATION OF HORSERADISH PEROXIDASE CONJUGATE

The performance of the horseradish peroxidase conjugate in the antinuclear factor system was $\frac{D}{2}$ evaluated by block titration as described for the fluorescein isothyocyanate conjugate (Holborow and $\mathrm{N}$ Johnson, 1967). Dilutions of an antinuclear factor- $N$ positive serum were tested against dilutions of the horseradish peroxidase conjugate. A range of stain- $\omega$ ing intensities resulted enabling titration end-points corresponding to the lowest level of reactivity to be recorded. The results are shown in Figure 2. It will be seen that a constant titre for the antinuclear factor serum was obtained over a range of dilutions $\overline{0}$ of the horseradish peroxidase conjugate. The histo- $\overrightarrow{\mathbb{D}}$ gram shows a plateau similar to that obtained when $\frac{\cap}{\mathbb{D}}$ fluorescent conjugates are tested in this way. 


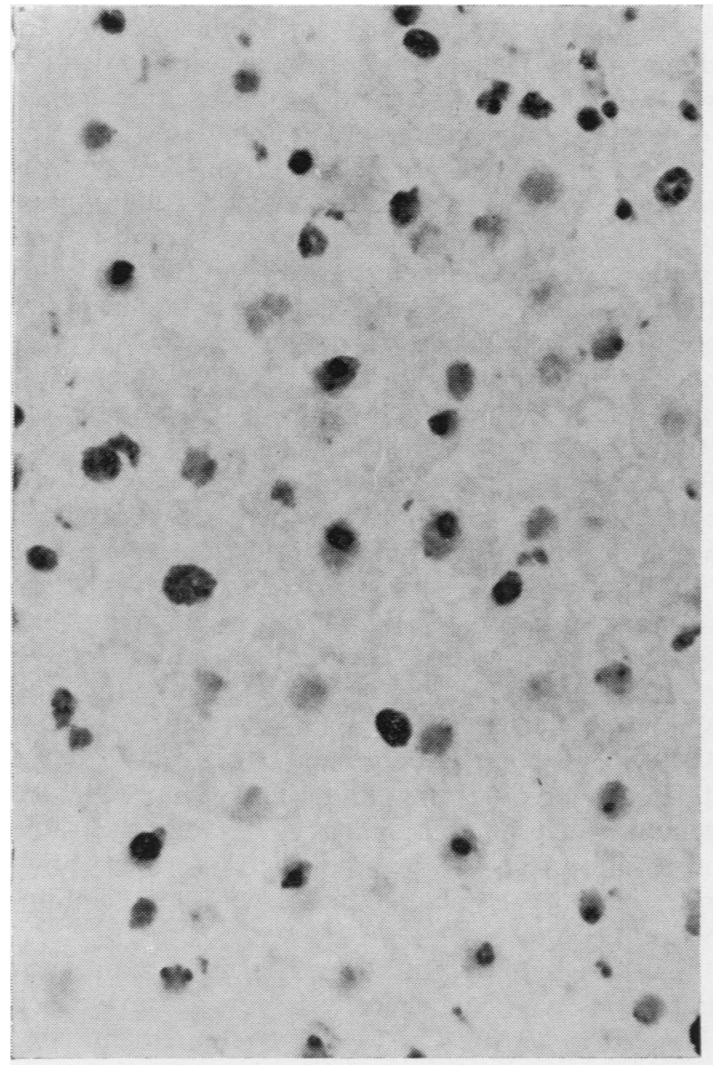

A

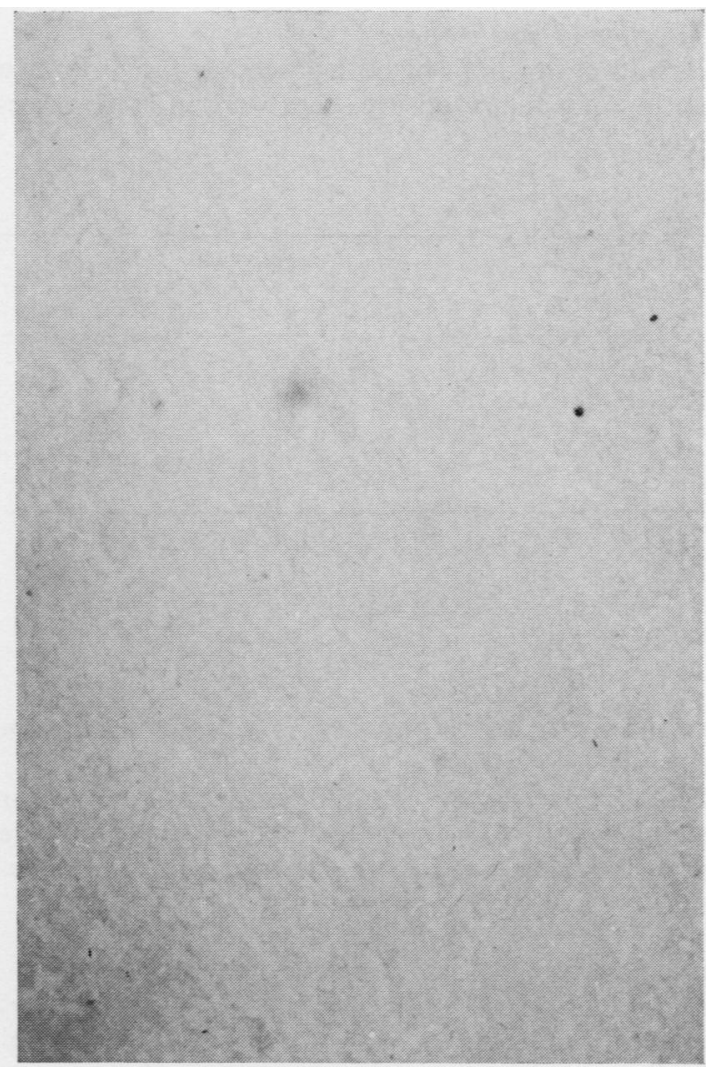

B

Fig. 1 Detection of antinuclear factor by horseradish peroxidase method $(\times 500)$. a Positive result. b Negative result.

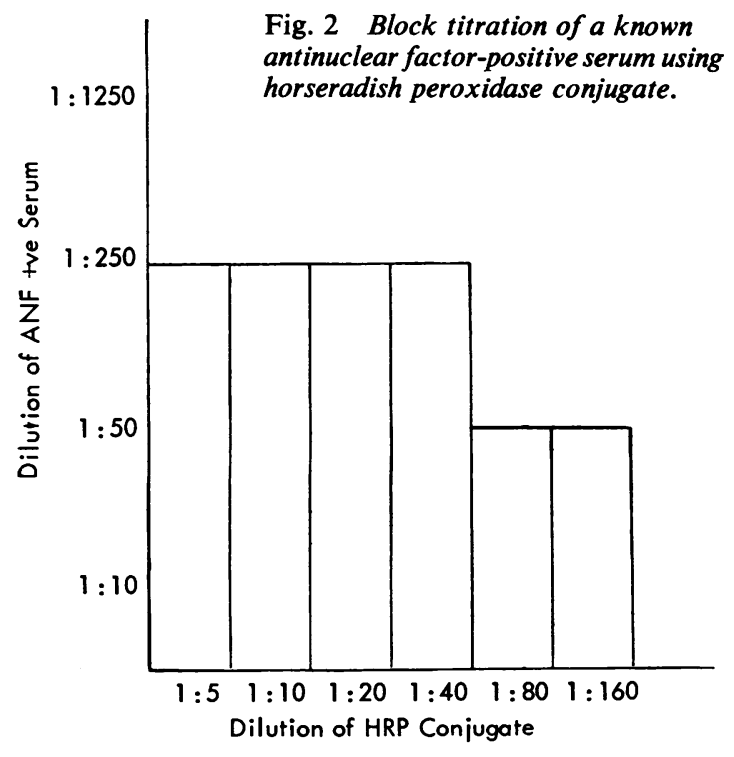

ASSESSMENT OF HORSERADISH PEROXIDASE CONJUGATE FOR USE IN ROUTINE ANTINUCLEAR FACTOR TESTS

\section{Detection of positive sera}

Twenty-four sera were tested for antinuclear factor by both methods. The horseradish peroxidase conjugate was used at a dilution of $1: 10$. Ten sera were positive and 14 negative by both methods. Details of results are shown in Table $I$.

\begin{tabular}{lcc}
\hline Degree of Staining & \multicolumn{2}{l}{ Number of Sera } \\
\cline { 2 - 3 } & FITC Conjugate & HRP Conjugate \\
\hline Positive & 4 & 5 \\
Weak positive & 3 & 2 \\
Very weak positive & 3 & 3 \\
Negative & 14 & 14 \\
\hline
\end{tabular}

Table I Comparison of results with two conjugates

1FITC = fluoreszein isothyocyanate.

${ }^{2} \mathbf{H R P}=$ horseradish peroxidase. 
Titration of positive sera

Results of titrations by both procedures of six known antinuclear factor-positive sera were in close agreement (Table II).

\begin{tabular}{lcc}
\hline $\begin{array}{l}\text { Serum } \\
\text { No. }\end{array}$ & \multicolumn{2}{l}{ Antinuclear Factor Titre } \\
\cline { 2 - 3 } & FITC Conjugate & HRP Conjugate \\
\hline 1 & $1: 250$ & $1: 250$ \\
2 & $1: 1250$ & $1: 1250$ \\
3 & $1: 1250$ & $1: 250^{1}$ \\
4 & $1: 1250$ & $1: 1250$ \\
5 & $1: 250$ & $1: 250$ \\
6 & $1: 250$ & $1: 250$ \\
\hline
\end{tabular}

Table II Results of titrations by both procedures

'Not tested at higher dilution than $1: 250$.

${ }^{2}$ FITC = fluorescein isothyocyanate.

${ }^{\mathrm{s}} \mathrm{HRP}=$ horseradish peroxidase.

DETECTION OF VARIANTS OF THE NUCLEAR STAINING PATTERN

Sera giving homogeneous, speckled, or nucleolar staining with fluorescein isothyocyanate conjugate gave the same pattern when tested with the horseradish peroxidase conjugate.

DETECTION OF OTHER AUTOANTIBODIES

Preliminary tests indicated that horseradish peroxidase conjugates may also be used to detect antibodies reacting with gastric parietal cells, smooth muscle, mitochondria, 'bile canaliculi', and thyroid microsomes. In these tests the conjugate was absorbed with a suspension of rat liver as previously described (Holborow and Johnson, 1967).

\section{Discussion}

In this study the fluorescence readings were made by experienced observers using darkground illumination with which positively stained nuclei appear bright apple-green against a dark background. The appearance of horseradish peroxidase tests, however, was unfamiliar and their brown colour provided less intense contrast. Nevertheless, when bias was eliminated by randomization of tests, the results show a striking correlation of sensitivity between the two methods. This finding suggests that the horseradish peroxidase method may provide a useful alternative to immunofluorescence for the detection of antinuclear factor and perhaps also for detecting other tissue-reactive antibodies.

The advantages of the horseradish peroxidase procedure over immunofluorescence are: (1) a simple light microscope is required; (2) preparations are permanently mounted; $(3)$ the reaction product is not subject to bleaching during microscopy. Although an extra step is necessary in order to demonstrate uptake of horseradish peroxidase the increase in staining time is only about 20 minutes.

Counterstaining may be helpful in localizing the reaction product and has been successfully applied to tissues after histochemical demonstration of peroxidase (see especially Straus, 1970a and b; Lillie, 1965; Pearse, 1960). Thus eosin and light green have been used to stain cytoplasm and connective tissue; nuclear stains, including methyl green, methylene blue, basic fuchsin, and Mayer's haemalum and Romanovsky type stains, have also been employed. Faint staining of peroxidase might be obscured by counterstaining which should therefore be avoided when maximum sensitivity is required.

Other substrates for peroxidase give different coloured reaction products, eg, benzidine (blue) (Adler and Adler, 1904; Straus, 1964) and 3-amino-9 ethylcarbazole (red) (Graham, Lundholm, and Kanovsky, 1965). They should give better contrast with some counterstains and may also enable different specific immunological reactions to be demonstrated in contrasting colours in the same preparation. The reaction products formed, however, are less stable than that from diaminobenzidine.

The desirability of characterizing fluorescent conjugates physicochemically is now acknowledged (Holborow, 1970). The essential requirements are: (1) adequate antibody activity, (2) optimal fluorochrome: protein labelling ratio, and (3) absence of unconjugated antibody and free fluorochrome. A similar degree of characterization of horseradish peroxidase conjugates may be desirable.

The reaction products from diaminobenzidine after treatment with osmium tetroxide can be readily identified in electron micrographs (Graham and Karnovsky, 1966). Fixation of tissues is essential for ultrastructural studies and must precede staining. Hoedemaecker and Ito (1970) have described the ultrastructural localization of gastric parietal cell antigen by the use of horseradish peroxidase conjugates of IgG obtained from patients with pernicious anaemia. It was found during the present work that short fixation of tissue sections with formaldehyde did not prevent their subsequent reaction with the autoantibodies tested, and it seems likely therefore that ultrastructural localization of the antigens involved in these reactions may also be possible.

Many animal tissues normally show peroxidase activity. Although this presented no difficulty in this study its presence could make interpretation difficult. Methods are being sought for the irreversible inhibition of endogenous activity. 
We wish to thank Dr E. J. Holborow for his helpful comments on the manuscript.

\section{References}

Adler, O., and Adler, R. (1904). Ueber das Verhalten gevisser organischer Verbindungen gegenüber Blut mit besonderer Berucksichtigung des Nachweises von Blut. Hoppe-Saylers Z. physiol. Chem., 41, 59-67.

Beutner, E. H., Holborow, E. J., and Johnson, G. D. (1967). Quantitative studies of immunofluorescent staining. I. Analysis of mixed immunofluorescence. Immunology, 12, 327-337.

Coons, A. H., and Kaplan, M. H. (1950). Localization of antigen in tissue cells. II. Improvements in a method for the detection of antigen by means of fluorescent antibody. J. exp. Med., 91, 1-13.

Davey, F. R., and Busch, G. J. (1970). Immunohistochemistry of glomerulonephritis using horseradish peroxidase and fluorescein labeled antibody: a comparison of the two technics. Amer. J. clin. Path., 53, 531-536.

Graham, R. C. Jr, and Karnovsky, M. J. (1966). The early stages of absorption of injected horseradish peroxidase in the proximal tubules of mouse kidney: ultrastructural cytochemistry by a new technique. J. Histochem. Cytochem., 14, 291-302.

Graham, R. C., Lundholm, U., and Karnovsky, M. J. (1965). Cytochemical demonstration of peroxidase activity with 3-amino9-ethylcarbazole. J. Histochem. Cytochem., 13, 150-152.

Holborow, E. J. (1970). In Standardization in Immunofluorescence, edited by E. J. Holborow, pp. 91-93. Blackwell Scientific Publications, Oxford and Edinburgh.

Holborow, E. J., and Johnson, G. D. (1967). In Handbook of Experimental Immunology, edited by D. M. Weir, p. 584. Blackwell Scientific Publications, Oxford and Edinburgh.
Holborow, E. J., and Johnson, G. D. (1969). The immunofluorescent test for serum antinuclear factor. Association of Clinical Pathologists. Broadsheets, 65.

Holborow, E. J., Weir, D. M., and Johnson, G. D. (1957). A serum factor in lupus erythematosus with affinity for tissue nuclei. Brit. med.J., 2, 732-734.

Hoedemaecker, P. J., and Ito, S. (1970). Ultrastructural localization of gastric parietal cell antigen with peroxidase-coupled antibody. Lab. Invest., 22, 184-188.

Johnson, G. D., Beutner, E. H., and Holborow, E. J. (1967). Developments in immunofluorescence: the need for standardization. J. clin. Path., 20, 720-723.

Lillie, R. D. (1965). Histopathologic Technic and Practical Histochemistry, 3rd ed. McGraw-Hill, New York.

Marshall, J. D., Eveland, W. C., and Smith, C. W. (1958). Superiority of fluorescein isothiocyanate (Riggs) for fluorescent-antibody technic with a modification of its application. Proc. Soc. exp. Biol. (N.Y.), 98, 898-900.

Nakane, P. K., and Pierce, G. B., Jr. (1966). Enzyme-labeled antibodies: preparation and application for the localisation of antigens. J. Histochem. Cytochem., 14, 929-931.

O'Neill, P., and Johnson, G. D. (1970). Multispot immunofluorescence: a simple semi-automatic method of processing large numbers of tests. J. clin. Path., 23, 185-187.

Pearse, A. G. E. 1960). Histochemistry: Theoretical and Applied, 2nd ed. Churchill, London.

Straus, W. (1970a). Location of antibody to horseradish peroxidase in popliteal lymph nodes of rabbits during the primary and early secondary response. J. Histochem. Cytochem., 18, 120-130.

Straus, W. (1970b). Localisation of the antigen in popliteal lymph nodes of rabbits during the formation of antibodies to horseradish peroxidase. J. Histochem. Cytochem., 18, 131-142.

Straus, W. (1964). Factors affecting the cytochemical reaction of peroxidase with benzidine and the stability of the blue reaction product. J. Histochem. Cytochem., 12, 462-469. 